\title{
OSBP2 Gene
}

National Cancer Institute

\section{Source}

National Cancer Institute. OSBP2 Gene. NCI Thesaurus. Code C125578.

This gene plays a role in binding to oxysterols. 